\title{
MICROORGANISMS AS TOOLS IN MODERN CHEMISTRY: THE BIOTRANSFORMATION OF 3-INDOLYLACETONITRILE AND TRYPTAMINE BY FUNGI
}

\author{
Maria Amélia D. Boaventura; Rosiane F.A.P. Lopes; Jacqueline A. Takahashi* \\ Departamento de Química, Instituto de Ciências Exatas, Universidade Federal de Minas Gerais, Belo Horizonte, MG, Brasil \\ Submitted: June 22, 2004; Returned to authors for corrections: September 13, 2004; Approved: November 26, 2004
}

\begin{abstract}
Chemical reactions performed by microorganisms have been used as a modern tool in chemistry. In this work, the ability of the fungi Beauveria bassiana and Aspergillus niger to modify the chemical structure of indole compounds was studied. Beauveria bassiana was able to transform 3-indolylacetonitrile into 3-methylindole while Aspergillus niger transformed tryptamine into 5-hydroxyindole-3-acetamide. Interestingly, these fungi were able to perform both reduction and oxidation of the indole compounds fed, the oxidation occurring with improved levels of oxygen uptake. The results prove once more the versatility of microorganisms to perform a wide range of industrially attractive chemical reactions.
\end{abstract}

Key words: Biotransformations, Beauveria bassiana, Aspergillus niger, 3-indolylacetonitrile, tryptamine

\section{INTRODUCTION}

The use of microorganisms in chemistry is not a new issue. Bacteria and fungi have been used to produce chemicals, pharmaceuticals and perfumes for decades $(1,8)$. Microorganisms can also be successfully used for pollutants degradation and recovery of the environment contaminated by chemicals (7). Their use for modifying the chemical structures of natural products is more recent but very well documented (4). However, the use of this methodology by the industry is still modest, considering the great availability of useful microorganisms and the large scope of useful reactions that can be accomplished by them. Considering the modern requirements for a more safe and ecological chemistry (3), the use of reactions performed by microorganisms tends to an increase in the near future. Such reactions, usually refereed as biotransformations, have some advantages over the conventional chemical reactions. Biotransformations are usually carried out in aqueous systems and at a neutral $\mathrm{pH}$, avoiding the use of harmful solvents common in conventional syntheses. In addition to this, microorganisms are able to perform a large variety of reactions, including some nearly inaccessible by chemical means.
Description of new useful reactions is, therefore, of interest. The biotransformations of indol compounds are of special interest because of the large scope of their biological activities. They can be used to treat many diseases, such as arthritis, skin diseases, headaches and glaucoma (2). Tryptamine, for example, has a welldescribed action on the central nervous system and can also be used as anti-feeding and anti-attractive compounds over Drosophila melanogaster $(9,12)$. 5-Hydroxytryptamine is a very powerfull vasoconstrictor agent called serotonin. The synthetic use of microorganisms to perform reactions in the indol nucleus is of industrial interest as a way to synthesize active indole derivatives and this area has attracted great attention (4). Our group is interested on useful reactions that can be performed by microorganisms, and we have been presenting many options towards the conventional chemistry in this area (11).

In this way, we report herein the action of Beauveria bassiana and Aspergillus niger over 3-indolylacetonitrile (1) and tryptamine $(\mathbf{3})$, respectively.

\section{MATERIALS AND METHODS}

Solvents (ethyl acetate, ethanol, methanol, petrol ether) from Merck were of analytical grade. Silica gel 60 and 60G were

*Corresponding author. Mailing address: Departamento de Química, Instituto de Ciências Exatas, UFMG, Av. Antonio Carlos, 6627. 31270-901, Belo Horizonte, MG, Brasil. Tel.: (+5531) 3499-5754, Fax (+5531) 3499-5700. E-mail: jat@qui.ufmg.br 
purchased from Sigma-Aldrich (Milwaukee, WI, USA). Sephadex LH-20 was purchased from Sigma (St. Louis, MO, USA). Reagents to prepare the culture medium were purchased from Difco (Sparks, MD, USA).

Stock cultures of Beauveria bassiana (CCT 3161) and Aspergillus niger (NRRL 4026) were maintained on malt agar under refrigeration. Cultures were donated by Coleção de Culturas Tropical (Campinas, SP, Brazil) and National Center for Agricultural Utilization Research (Peoria, IL, USA). Small sections of this agar were transferred to Erlenmeyer's flasks containing a liquid medium ( $200 \mathrm{~mL} / \mathrm{flask})$ comprised of $(\mathrm{g} / \mathrm{L})$ : glucose (20.0), peptone (5.0), yeast extract (3.0), potassium phosphate (5.0) in distilled water and $\mathrm{pH}$ was adjusted to 6.0 with a solution of aqueous $\mathrm{NaOH}(1 \mathrm{~mol} / \mathrm{L})$. The culture was incubated over magnetic stirring ( $72 \mathrm{~h}$ for $B$. bassiana and $40 \mathrm{~h}$ for $A$. niger) to reach stage I. Cells ( $15 \mathrm{~mL}$ portions) on stage I were transferred to new flasks and, in both cases, reached stage II (abundant growth) after 24 hours when the substrates (1mL/flask) were added [3-indolylacetonitrile (1) to $B$. bassiana and tryptamine (3) to A. niger] as a solution in ethanol $(50 \mathrm{mg} / \mathrm{mL})$. After 13 days, the flasks' contents were extracted with ethyl acetate and the solvent was taken out under vacuum. Residue (326 mg) from the experiment with $B$. bassiana was chromatographed over silica gel (petrol ether/ethyl acetate/methanol). Fractions eluted from petrol ether:ethyl acetate 8:2 furnished a solid (23 $\mathrm{mg}$ ) identified by spectroscopic means as 3-methylindol (2). From the experiment with A. niger, the residue (680 mg) was then dissolved in methanol and repeatedly chromatographed over Sephadex LH-20 using methanol as eluent to furnish a solid (12 mg) identified as 5-hydroxyindole-3-acetamide (4).

\section{RESULTS AND DISCUSSION}

The biotransformation of 3-indolylacetonitrile (1) by $B$. bassiana led to the formation of a solid less polar than the starting material. This compound was identified as 3-methylindole (2) by using ${ }^{1} \mathrm{H}$ and ${ }^{13} \mathrm{C}$ NMR techniques. The presence of a new methyl group in the molecule was confirmed in the ${ }^{1} \mathrm{H}$ NMR spectrum due to a singlet at $\delta 2.33$ integrating for 3 hydrogens. The corresponding carbon signal was observed at $\delta 9.86$ in the ${ }^{13} \mathrm{C}$ NMR spectrum. The disappearing of the signal at $\delta c 118.38$ of the starting material was also observed and this is in accordance with the cleavage of the $\mathrm{CN}$ group from the starting material. Full ${ }^{1} \mathrm{H}$ and ${ }^{13} \mathrm{C}$ NMR spectra assignment for compound 2 can be found in Tables 1 and 2, respectively. Coupling constants ( $J$ values) of aromatic hydrogens are, according to the expected values, showing that no alterations on the aromatic ring substitution pattern has occurred. ${ }^{13} \mathrm{C}$ NMR data for compound $\mathbf{1}$ (starting material) is also presented for comparison purposes. Absence of $\mathrm{CN}$ group at $\mathrm{C}-3$ changed the chemical shift of this carbon from $\delta \mathrm{c} 103.97$ to $\delta \mathrm{c} 112.19$, while C-10 shifted from $\delta \mathrm{c} 14.03$ to 9.86 . Interestingly, 3-methylindole (2) was also obtained when 3indolacetic acid was fed to Pseudomonas sp (4). The fact that microorganisms can metabolize different indole derivatives into 3-methylindole suggests that the synthesis of this compound by using biological reagents can be successfully addressed and even improved. This observation can also be useful for biosynthesis studies of interesting naturally occurring indol compounds, especially those of fungal origin (5).

When tryptamine (3) was fed to A. niger, compound 4 was recovered after chromatography step. Analysis of $\mathbf{4}$ by ${ }^{1} \mathrm{H}$ NMR showed, in the aromatic region, signals for 4 aromatic hydrogens. Therefore, a new group replaced one hydrogen from the aromatic ring. Careful analysis of the aromatic hydrogens region profile showed that the substitution occurred at C-5. Analysis of the ${ }^{13} \mathrm{C}$ NMR spectra showed the presence of a new signal at $\delta$ 148.72 and the disappearing of C-5 signal, both good indications that $\mathrm{C}-5$ was hydroxylated. The ${ }^{13} \mathrm{C}$ resonance of $\mathrm{C}-11$ was not

Table 2. Full ${ }^{13} \mathrm{C}$ NMR assignment $\left(\delta, \mathrm{D}_{2} \mathrm{O}, 50 \mathrm{MHz}\right)$ for $3-$ indolylacetonitrile (1), 3-methylindole (2), tryptamine (3) and 5hydroxyindole-3-acetamide (4).

\begin{tabular}{rrrrr}
\hline C & $\mathbf{1}$ & $\mathbf{2}$ & $\mathbf{3}$ & $\mathbf{4}$ \\
\hline 2 & 122.83 & 122.12 & 122.13 & 125.60 \\
3 & 103.97 & 112.19 & 113.26 & 115.50 \\
4 & 117.78 & 119.18 & 118.72 & 111.60 \\
5 & 122.51 & 121.81 & 119.03 & 148.72 \\
6 & 119.88 & 119.18 & 121.77 & 112.60 \\
7 & 111.49 & 111.18 & 111.14 & 102.62 \\
8 & 125.57 & 128.81 & 127.36 & 127.37 \\
9 & 136.05 & 136.82 & 136.40 & 131.35 \\
10 & 14.03 & 9.86 & 29.29 & 31.09 \\
11 & 118.38 & - & 42.17 & 177.96 \\
\hline
\end{tabular}


observed, but a new signal was observed at $\delta 177.96$, indicating the oxidation of this carbon. Table 2 shows the complete ${ }^{13} \mathrm{C}$ NMR data assignment for compound $\mathbf{4}$, in comparison to data of the starting material tryptamine (3). From the best of our knowledge, NMR data for compound $\mathbf{4}$ is not reported in the literature (6). Hydroxylation of an indole nucleus (3-indoleacetic acid) at C-5 by Aspergillus niger is reported (4).

Both experiments were carried out with and without orbital shaking. Interestingly, in the biotransformations of 3indolylacetonitrile by $B$. bassiana, the product (3-methylindole) was only observed for the experiment without shaking. 3methylindole, formed by reduction of the precursor 3indolylacetonitrile, was neither isolated nor detected by TLC when the cells were shaken. On the other hand, in the biotransformations of tryptamine by A. niger, the product 5hydroxyindole-3-acetamide results from the oxidation of the substrate. In this case, it was only produced when the experiment was shaken. These observations show the importance of an adequate oxygen uptake for the synthesis of oxidative products, especially hydroxylated derivatives (10).<smiles>N#CCc1c[nH]c2ccccc12</smiles><smiles>NCCc1c[nH]c2ccccc12</smiles>

3<smiles>Cc1c[nH]c2ccccc12</smiles>

2<smiles>NC(=O)Cc1c[nH]c2ccc(O)cc12</smiles>

Figure 1. Chemical structures of 3-indolylacetonitrile (1), 3methylindole (2), tryptamine (3) and 5-hydroxyindole-3acetamide (4).

\section{ACKNOWLEDGMENTS}

To FAPEMIG for financial help. To Coleção de Culturas Tropical (Campinas, SP, Brazil) and National Center for Agricultural Utilization Research (Peoria, IL, USA) for donation of the microorganisms.

\section{RESUMO}

\section{Microrganismos como ferramentas na química moderna: a biotransformação da 3 -indolilacetonitrila e triptamina por fungos}

O uso de microrganismos para a realização de reações químicas tem sido explorado como uma ferramenta moderna em química. Neste trabalho explorou-se a habilidade dos fungos Beauveria bassiana e Aspergillus niger de modificarem quimicamente a estrutura de compostos indólicos, uma classe de substâncias com diversas atividades biológicas relatadas. A 3-indolacetonitrila foi reduzida, com formação do 3-metilindol por Beauveria bassiana, enquanto Aspergillus niger converteu a triptamina em um derivado oxidado, a 5-hidroxiindol-3-acetamida. A oxidação ocorreu somente no experimento sob agitação e provavelmente está relacionada ao alto grau de oxigenação da reação. A ocorrência de redução e oxidação de derivados indólicos ilustra bem a versatilidade do uso de microorganismos para a condução de uma grande variedade de reações químicas de interesse industrial.

Palavras-chave: biotransformações, Beauveria bassiana, Aspergillus niger, 3-indolacetonitrila, triptamina

\section{REFERENCES}

1. Demain, A.L. Pharmaceutically active secondary metabolites of microorganisms. Appl. Microbiol. Biotechnol., 52:455-463, 1999.

2. Gupta, P.; Lahuerta, J.; Jones, S.; Robson, S.F.; Samuels, G.M.R.; Wilson, A.B.; Wythes, M.J.; Monkhouse, K.L.; Land, G.C. PCT Int. Appl., WO 9611685 A2, 1996, 10p.

3. Hawari, J.; Halasz, A.; Beaudet, S.; Paquet, L.; Ampleman, G.; Thiboutot, S. Biotransformation of 2,4,6-trinitrotoluene with Phanerochaete chrysosporium in agitated cultures at $\mathrm{pH}$ 4.5. Appl. Environm. Microbiol., 65:2977-2986, 1999.

4. Kieslich, K. Microbial Transformations, John Wiley \& Sons, Stuttgart, 1976,1262 p.

5. King, R.R.; Lawrence, C.H.; Calhoun, L.A. Unusual production of 5nitroanthranilic acid by Streptomyces scabies. Phytochemistry, 49: 1265-1267, 1998.

6. Koo, J.; Avakian, S.; Martin, G.J. Synthesis in the 5-hydroxyindole series. N-acetyl-5-hydroxytryptophan and related compounds. $J$. Org. Chem., 24:179-183, 1959.

7. Korol, S.; Natale, P.; Moretton, J.; Santini, P.; D’Aquino, M. Isolation and characterization of a new para-chlorophenol degrading strain of Pseudomonas from samples of natural waters. Rev. Microbiol., 22:313-318, 1991.

8. Kurtzman, C.P. Fungi - Sources of food, fuel and biochemicals. Mycologia, 75:374-382, 1983.

9. O'Connor, K.E.; Dobson, A.D.W.; Hartmans, S. Indigo formation by microorganisms expressing styrene monooxygenase activity. Appl. Environm. Microb., 63(11):4287-4291, 1997.

10. Takahashi, J.A.; Barroso, H.A.; Oliveira, A.B. Optimization of diterpenes bioconversion process by the fungus Cephalosporium aphidicola. Braz. J. Microbiol., 31:81-86, 2000.

11. Vieira, H.S.; Takahashi, J.A.; Boaventura, M.A.D. Biotransformation of methyl ent-17-hydroxy-16ß-kauran-19-oate by Rhizopus stolonifer. Appl. Microbiol. Biotechnol., 53:601-604, 2000.

12. Wurst, M.; Kysilka, R.; Koza, T. Analysis and isolation of indole alkaloids of fungi by high-performance liquid chromatography. $J$. Chromat., 583:201-208, 1992. 